\title{
THE RELATION OF EDUCATIONAL SUPERVISION AND TEACHER'S TEACHING SKILLS
}

\author{
Maisyaroh \\ State University of Malang, Indonesia \\ maisyaroh.fip@um.ac.id \\ Bambang Budi Wiyono \\ State University of Malang, Indonesia \\ bambang.budi.fip@um.ac.id
}

\author{
Burhanuddin \\ State University of Malang, Indonesia \\ burhanuddin.fip@um.ac.id \\ Ach. Rasyad \\ State University of Malang, Indonesia \\ rasyadplsum@yahoo.co.id
}

\begin{abstract}
The development of science and technology demands teachers to provide better education to the students and appropriate with the demands. One way to encourage teachers to develop their abilities can be performed through educational supervision. This study is aimed at identifying the correlation between the implementation of educational supervision and the teaching skills of the teachers. This study was conducted in Malang City, using correlational descriptive design. 144 teachers as samples were taken from Junior High School with proportional random sampling technique. Data collection techniques that used in this study was questionnaires, while the technique of data analysis was descriptive statistics and correlation techniques Pearson product moment and linear regression. The results showed that teacher's teaching skills was good, and the supervision was also sufficient. There is a significant positive correlation between the frequency and principle of supervision implementation and teacher's teaching skills.
\end{abstract}

Keywords: supervision frequency, supervision principle, teaching skills, teacher

\section{INTRODUCTION}

One of the main determining factors in improving the quality of education is the teachers. The quality of education is mainly determined by the quality of teacher's teaching skillls. If the teacher can teach well, it will improve the quality of student learning process and results. Therefore, to improve the quality of education, it is necessary to always improve teacher's teaching skills.

Teaching is essentially to facilitate students learning process. If it is viewed from the process of its activities, teaching is a complex activity. It contains elements of science, technology, and art. It is defined as a science, because its principles are structured with reasons that have to be supported by scientific research. It refers to technology, because its procedure is described, and it applies the theories of science, particularly the science of education. It is called as an art, because the embodiment in teaching and learning process is transactional, mostly are based on personal considerations or intuition (Raka Joni, 1980)

One effective way to improve teacher's teaching skills is through the supervision. Supervision is essentially a process of providing assistance to the teachers by providing encouragement, stimulation, or guidance to fix and improve the teaching and learning process. The distribution of assistance can be done through several techniques, including seminars, upgrades, workshops, discussions, meetings, teaching demonstrations, and class visits.

On the other hand, the rapid development of science and technology requires the teachers to provide instruction that agrees with the existing developments. Recently reforms in the field of education is difficult to be followed by teachers who are already familiar with the traditional education system. So, this encourages the need to provide supervision to the teachers. Supervision is absolutely required by the teacher philosophically, sociologically, culturally, and psychologically.

The results of Misno (1998) showed that the implementation of supervision activities still has not shown the maximum results. Likewise, the results of Zakaria (1990) research also found that the skills of implementation the supervision of the school principal are still in the medium category. The government has taken new steps to improve the implementation of educational supervision. Some of the key policies are promoting intensive teacher-building activities for all the teachers, including pre-school education, primary education, and secondary education through continuous professional development.

Through these policies, it is expected that the activities of educational supervision can be implemented more effectively. The school principal as an educational leader has the primary responsibility to carrying out supervision at school. However, how high the quality of supervision still remains a question. How high the influence of supervision on teacher's teaching skills is still a question. Based on that rationale, this study is conducted.

This study is aimed at describing the implementation of educational supervision and teachers teaching skills, especially in Junior High School Malang. The main purpose of this study is to determine the coefficient relationship between the frequency and principles of educational supervision followed by the teachers and the teacher's teaching skills. The frequency of supervision is seen from intensity of the implementation of the applied supervision techniques, both group and individual. The principle of supervision is seen from the basic norms referred to the implementation of supervision such as friendly, objective, democratic, constructive, creative, cooperative, objective, open, and scientific. Teacher's teaching skills are seen from four components, namely 
skills in teaching, skills in managing core activities, skills in time management, and skills in assessing learning outcomes.

The proposed hypothesis is that there is a positive correlation between the frequency and the principle of educational supervision followed by the teacher and the teachers teaching skills. To prove the hypothesis, it is necessary to collect and test data in the field.

This research is very useful, both theoretically and practically. Theoretically, the results of this study can be used to develop a theory of educational or teaching supervision. Practically, the results of this study can be used for teachers as feedbacks to their teaching skills, and for the school principal, it is about the implementation of supervision. For the head of the education department or other officials, it may also provide beneficial information on the effectiveness of supervision that being performed. Through this study, as the main result, we can know the magnitude influence of educational supervision conducted on the teacher's teaching skills.

\section{METHODS}

This study employed descriptive correlational research design. The whole process of research, from data collection, data analysis, to the interpretation of data used descriptive correlational research design. This study was conducted in Malang city. As a research population is the teachers of Junior High School in Malang. The samples were 144 teachers who were selected using proportional random sampling technique.

The main data collection techniques used questionnaires and observations, then it was complemented by interviews and documentation. Questionnaires were used to collect data about the implementation of educational supervision, both the frequency and the principle of supervision. Observations were used to collect data about teacher's teaching skills. Interviews were used to dig deeper the data about the implementation of educational supervision, and documentation was used to complement documented data.

The research instrument was developed based on research variables. It started from analyzing the theory in depth, identifying the dimensions and indicators of research variables, as well as formulating research instrument items. Form of the instrument utilized the scale of the assessment, with a score of $1,2,3$, and 4 . To obtain the validity and reliability of the instrument, the researcher tested and analyzed instrument. The validity of the instrument was examined from the content and item validity. Instrument reliability was examined from internal consistency. The result of instrument analysis showed that the instrument was quite valid and reliable. There were 15 items of frequency of educational supervision, 12 items of principles of educational supervision, and 24 instrument items of teaching skills.

In accordance with research objectives, data analysis techniques used in this study was descriptive statistics and inferential statistics. Descriptive statistics are used to describe data, both on the implementation of supervision and teacher's teaching skills. The study used technique of frequency distribution and the average. While the inferential statistics used Product Moment Pearson correlation and linear regression.

\section{RESULTS AND DISCUSSION}

Based on the results of data analysis shows that the average value of teacher's teaching skills is 81.69. Viewed from the data distribution, there are four classifications of teacher's teaching skills, namely (a) 27.00 - 47.24 not good category, (b) 47.25 - 67.49 adequate category, (c) 67.50 - 87.74 good category, and (d) 87,75 - 108,00 very good category. Thus, the average teacher's teaching skill is categorized as a good category.

From the analysis results is also known that the average value of the frequency of implementing educational supervision is 26.67. The distribution of group data is classified into four as well, namely: (a) $15.00-26.24$ is not good category, (b) $26.25-32.49$ is adequate category, (c) $32.50-37.49$ is good category, and (d) 37,50 - 45,00 is very good category. Thus the average frequency of carrying out educational supervision is adequate.

From the analysis results also known that the average principle of implementation of educational supervision achieved 34.74. The distribution of group data for the implementation of educational supervision is also classified into four, namely: (a) $12.00-20.99$ as a bad category, (b) 21.00 - 29.99 is adequate category, (c) 30.00 - 38.99 is good category, and (d) 39,00 48,00 is very good category. Thus, the average principles of educational supervision that are carried out include to good category.

Then, hypothesis test is proposed. In accordance with the objectives of this study, the proposed hypothesis formulation is that there is a positive relationship between the frequency of educational supervision and the principle of educational supervision and the teacher's teaching skills. Based on the result of linear regression analysis achieved $\mathrm{R}$ Square value 0,435 with $p$ value $<0,05$. Thus, it can be concluded that there is a significant positive relationship simultaneously between the frequency of educational supervision and the principle of educational supervision that was implemented and the teacher's teaching skills. The higher the frequency of carrying out educational supervision, and the higher the use of the principles of educational supervision, the higher the teachers teaching skills. Implementation of educational supervision has a prediction power of $43.5 \%$.

When it is analyzed more deeply, each variable, the result of partial correlation analysis is presented in Table 1. Based on Table 1, it can be concluded that there is a significant positive relationship between the frequency of educational supervision and teacher's teaching skill. The more the teachers follow intensive supervision the higher teacher's teaching skills. From the analysis results can also be concluded that there is a significant positive relationship between the principle of educational supervision and the ability of teacher's 
teaching skills. The higher the use of the principles of educational supervision in the implementation of educational supervision the higher the teacher's teaching skills.

Table 1

Frequency Correlation Coefficient and Education Supervision Principles and Teachers Teaching Skills

\begin{tabular}{c|ccccc}
\hline No & \multicolumn{1}{|c}{ Independent Variable } & \multicolumn{1}{c}{ Dependent Variable } & $\mathbf{r}$ & $\mathbf{p}$ & Conclusion \\
1 & $\begin{array}{l}\text { Frequency of Educational } \\
\text { Supervision }\end{array}$ & Teachers teaching skills & 0.630 & $<0.01$ & Significant \\
2 & $\begin{array}{l}\text { Principles of Educational } \\
\text { Supervision }\end{array}$ & Teachers teaching skills & 0.406 & $<0.01$ & Significant \\
\hline
\end{tabular}

When it is examined from the theory and the results of previous studies indicate conformity. Educational Supervision is a technique to provide assistance, improve, and improve the ability of teachers, especially the ability to teach. The ultimate goal of educational supervision activities is the increasing situation, process, and learning outcomes of students.

The results of this study is suitable with the results of Misno's research (1988) which shows that the implementation of educational supervision in Junior High School in Malang has not been implemented optimally. The results of this study also showed that the average of the frequency of educational supervision which has been implemented includes to adequate category, and it is still not reached good or very good category.

When it is examined more deeply, there are several causes or rational. First, in Indonesia, generally, implementing supervision is not a habit. Neither the school principal nor the school supervisor who has the duty to carry out supervision is still not aware of and has a qualified ability in accordance with the principles and techniques of correct supervision. Likewise the teacher as a supervisor is not receive full-hearted upon supervision. Besides, career development system based on achievement is not yet fully implemented, so the role of supervision function can not be utilized optimally. That is the rational of not maximal implementation of educational supervision.

The result of hypothesis test shows that there is a significant positive correlation between the frequency of educational supervision and teacher's teaching skills, between the principle of educational supervision and teacher's teaching skills, and between the frequency and the principle of educational supervision and teacher's teaching skills. It shows that there is a strong influence of educational supervision activity on teacher's teaching skills. The results of this study corroborate the results of Djailani's research (Zakakaria, 1990) which indicated that there is a positive correlation between the school principal's supervision and the teacher's teaching skills The results of this study also agree with the results of Wiyono and Brhanuddin's research (2015) which showed that there is a positive relationship between teacher involvement in teacher working group meeting activities and teacher's teaching skills. Teacher working group meeting is one of the techniques of educational supervision.

The results of this study also refers to some other previous studies. The research results of Bisset and Nichol (1998) showed that professional development of teachers can improve the teachers professional ability. Raudenbush (1993) resulted that teacher development activities have an impact on teacher's teaching skills. The results of this study are also agrees with the results of Al-Zoubi \& Rahman's research (2011) which showed that there is a positive impact of training programs on the competence of special education teachers. The results of Azis \& Akhtar's research (2014) also stated that there is an influence of training on teacher's competence. The training program is one of the supervision techniques. The results of this study are also in line with the results of Suporvits \& Truner' research (2000) that indicated that development programs that emphasize teacher participation have a strong influence on teacher's teaching performance. The results of this study also agrees with the results of Wiyono's research (2017) which found that there is a positive influence of selfevaluation activities on improving transformational leadership skills of the school principals, teacher motivation, and effectiveness of teacher team work. The result of Tambunan's research (2014) also mentioned that self-developmen is one of the factors that influence the improvement of teacher competence. Self-evaluation and self-development is one of the techniques of educational supervision.

\section{CONCLUSION}

Based on the results of this study, it can be presented the main findings in this study. Firs, the educational supervision has not been fully implemented in appropriate with its role and function. The frequency classification of the implementation of educational supervision is in sufficient category. According to some previous research findings show that educational supervision, especially teaching supervision, has not been applied ideally in the field. The nature of supervision as a technique providing assistance to teachers to fix and improve the quality of the process and learning outcomes has not been done ideally. as a results, it needs to be constantly improved.

Based on the results of the study also found that there is a significant positive correlation of frequency and principle of educational supervision and teacher's teaching skills. The higher the intensity of carrying out educational supervision with the correct principles, the higher the teacher's teaching skills. This reinforces the theory and some previous research results, that supervision is the main technique to improve teacher's teaching skills. In general, there are two types of teacher development techniques, namely through pre- 
service and in-service education. Educational Supervision is a type of teacher development through in-service education. In-service education is an effective technique for improving teacher competence in accordance with the development of science, technology, and community culture. Therefore, educational supervision activities should always be performed, or even improved on an ongoing basis to improve the teachers professionalism in performing their duties.

The results of this study is not a final study. In order to obtain generalizations and deeper findings, further research is needed with more precise methodologies, and a deeper study of each applied supervision technique. Hence, it will take a more comprehensive and meaningful conclusion, both for the development of theory and the practical importance of task implementation in schools, in order to achieve better quality of education.

\section{REFERENCES}

[1] Al-Zoubi, S. M., and Rahman, M. S. B. A. 2011. The Effect of a Training Program in Improving Instructioal Competencies for Special Education Teachers in Jordan. Education Research, 2(3): 1021-1030.

[2] Aziz, F., \& Akhtar, M. M. S. 2014. Impact of Training on Teachers Competencies at Higher Education Level in Pakistan. Journal of Arts, Science \& Commerce, $\mathrm{V}(1): 121-128$.

[3] Bisset, R. T., and Nichol, J. 1998. Sense of Professionalism the Impact of 20-day Courses in Subject in Subyect Knowledge on the Professional Development of Teachers. Teacher Development, 2(3): 433-451.

[4] Joni, T. R. 1986. Cara Belajar Siswa Aktif, Implikasinya terhadap Sistem Pengajaran. Jakarta: Depdikbud.

[5] Misno. 1988. Hubungan antara Latar Belakang Pendidikan Formal Kepala SMP dengan Pelaksanaan Supervisi Pendidikan di Kotamadya Malang. Thesis. Malang: IKIP Malang.

[6] Raudenbush, S. W. 1993. On the Job Improvements in Teacher Competence: Policy Options and Their Effect on Teaching and Learning in Thailand. Educational Evaluation and Policy Analysis, 15(3): 279-297.

[7] Supovitz, J. A., \& Truner, H. M. 2000.The Effect of Professional Development on Science Teaching Practices and Classroom Culture. Journal of Research in Science Teaching, 37(9): 963-980.

[8] Tambunan, H. 2014. Factors Affecting Teachers' Competence in The Field of Information Technology, International Education Studies, 7(12): 70-75.

[9] Wardani, I. G. A. K. 1998. Program Pemberdayaan Guru. Jurnal Ilmu Pendidikan, 6(4): 289-301.

[10] Wiyono, B. B. 2017. The Effect of Self-Evaluation on The Principals' Transformational Leadership, Teachers' Work Motivation, Teamwork Effectiveness, and School Improvement. International Journal of Leadership in Education, Theory and Practice, April: $1-21$.

[11] Wiyono, B. B., \& Burhanuddin. 2015. Effects of the Meetings at Teachers' Working Group on Teacher's Teaching Quality. Journal of Education and Sociology, 6(2): 53-56.

[12] Wiyono, B. B., Ulfatin, N., \& Maisyaroh. 2008. Persepsi dan Sikap terhadap Program Sertifikasi,
Keikutsertaan dalam Kegiatan Pengembangan, dan Profesionalisme Guru. Manajemen Pendidikan, 22(2): 124-139.

[13] Zakaria, 1990. Keterampilan Supervisi Pengajaran Kepala SMPN menurut Persepsi Guru di Kotamadya Bengkulu. Thesis. Malang: IKIP Malang. 